\title{
Availability of Wild Edible Fungi in La Malinche National Park, Mexico
}

\author{
A. Montoya, ${ }^{1}$ A. Kong, ${ }^{1}$ R. Garibay-Orijel, ${ }^{2}$ C. Méndez-Espinoza, ${ }^{3}$ \\ Rodham E. Tulloss, ${ }^{4,5}$ and A. Estrada-Torres ${ }^{1}$ \\ ${ }^{1}$ Laboratorio de Biodiversidad, Centro de Investigaciones en Ciencias Biológicas, Universidad Autónoma de Tlaxcala, \\ Km 10.5 Autopista San Martín Texmelucan-Tlaxcala, 90120 Ixtacuixtla, TLAX, Mexico \\ ${ }^{2}$ Instituto de Biología, Universidad Nacional Autónoma de México, Circuito Exterior s/n, Ciudad Universitaria, \\ 04510 México, DF, Mexico \\ ${ }^{3}$ Instituto Nacional de Investigaciones Forestales, Agrícolas y Pecuarias (INIFAP)/Centro Nacional de Investigación Disciplinaria en \\ Conservación y Mejoramiento de Ecosistemas Forestales, Avenida Progreso No. 5, Colonia Barrio de Santa Catarina, \\ 04010 Coyoacán, DF, Mexico \\ ${ }^{4}$ P.O. Box 57, Roosevelt, NJ 08555-0057, USA \\ ${ }^{5}$ New York Botanical Garden, Bronx, NY, USA
}

Correspondence should be addressed to A. Montoya; ametnomicol@hotmail.com

Received 30 September 2013; Revised 22 December 2013; Accepted 28 December 2013; Published 5 March 2014

Academic Editor: Clemencia Chaves-Lopez

Copyright (C) 2014 A. Montoya et al. This is an open access article distributed under the Creative Commons Attribution License, which permits unrestricted use, distribution, and reproduction in any medium, provided the original work is properly cited.

\begin{abstract}
The aim of this paper is to compare edible mushroom availability between the two slopes of La Malinche National Park in central México, and to discuss the possible relation between their availability and traditional use. Eight transects were set up. Samples were collected weekly during the rainy seasons of years 1998-2000. Sixty-one edible mushroom species were collected from a total area of $3200 \mathrm{~m}^{2}$ ( $0.32 \mathrm{ha}$ ). Over the three-year period, the diversity of mushrooms ranged from 21 to 28 taxa per transect line. Sporocarps were produced at a rate from 2.06 to $6.05 \mathrm{~kg} / 401.51 \mathrm{~m}^{2}$. The highest species richness and production values for spatio-temporal frequency were obtained in Southeast slope. Edible mushrooms availability in the Southeast slope showed a strong dominance, driven mainly by Laccaria trichodermophora and Hebeloma mesophaeum. The Southwest slope had more diversified availability in time and space, with the most representative species, being L. trichodermophora. The characteristics of traditional management on each slope determined the differences found.
\end{abstract}

\section{Introduction}

"La Malinche" volcano (altitude $4460 \mathrm{~m}$ ) is one of the most important mountains in central México. Located in the Trans-Mexican Volcanic Belt, in the southern part of the state of Tlaxcala, it has been considered one of its eldest mountains (INEGI 1986). Most of its forests are protected as a National Park. However, timber and nontimber forest products are extracted as part of the subsistence strategy of local communities. People gather firewood, edible and medicinal plants, seeds, and moss and mushrooms and hunt small preys [1]. 226 species of macromycetes have been listed [2], 93 of which are used by local people as food, fuel, cosmetics, medicines, and insecticides [2, 3]. In the surroundings of
La Malinche, there are 236 villages [4], some inhabited by Nahua and Otomí indigenous descendants and others settled by mestizo people. In consequence, East and West forests are under different management practices [5]. In many of these localities, Amanita basii, Lyophyllum decastes, and Boletus pinophilus are the species with the highest cultural significance (cultural significance refers to the importance of the role that the organism plays within a particular culture [6]) [5]. As a preliminary suggestion, it has been proposed that both fruit body abundance and price are related to the cultural significance of species. Montoya et al. [7] found a negative correlation between the fruit body abundance and the mention frequency, suggesting that the most valued resources are not always the most abundant. 
It has been proposed that the volcano is regionalized into two cultural areas, based on the different valuations of mushroom species. There are several differences in the uses of the forest. In Javier Mina, a community located on Southeast slope of the volcano, $73.5 \%$ of the total population collects and sells mushrooms every year $[4,5]$. In the Southwest slope, in San Isidro Buensuceso, 21\% from a total of 220 persons sell wild mushrooms [4, 5]. Available information shows that mushrooms are used and granted value by people from both slopes; however, the use and importance of particular species are different in both sides. Nevertheless, there is scarce information about ecology parameters such as the fruit body production [8] and their relation with mushroom traditional use. The aim of this paper is to compare wild edible mushroom availability in the two slopes of "La Malinche" volcano and to assess the possible relation between availability and traditional use.

\section{Materials and Methods}

2.1. Study Area. La Malinche National Park is located between northern latitudes $97^{\circ} 55^{\prime}$ and $98^{\circ} 08^{\prime}$ and between western longitudes $19^{\circ} 20^{\prime}$ and $19^{\circ} 08^{\prime}$. The local climate is temperate subhumid with a rainy season in the summer $\left[\mathrm{C}\left(\mathrm{w}_{2}\right)(\mathrm{w})\right]$; the pressure/temperature ratio is 41.9 and there is little annual variation in average monthly temperatures, with fluctuations between $5^{\circ}$ and $7^{\circ}$. The annual mean temperature is $15.3^{\circ} \mathrm{C}$. May is the hottest month (mean temperature = $17.7^{\circ} \mathrm{C}$ ) and January is the coldest (mean temperature $=11^{\circ} \mathrm{C}$ ). Over $4000 \mathrm{~m}$, weather tends to be very cold, type E (T) H, with temperatures under $0^{\circ} \mathrm{C}$ in the coldest month [9].

There are three main vegetation kinds: a forest dominated by $P$. hartwegii in higher altitudes; a forest dominated by Pinus montezumae and P. teocote mixed with Alnus jorullensis, Quercus laurina, and Q. crassifolia in lower altitudes; and an Abies religiosa forest sometimes mixed with individuals of $P$. montezumae, $P$. hartwegii, Salix cana, S. paradoxa, and Juniperus monticola in some gullies.

2.2. Sampling. Eight sample units (SUs) were established for this study (Table 1). Four SUs (1-4) were placed in Southeast slope (4-7 km west of Francisco Javier Mina) and the other four (5-8) in the Southwest slope (6-7 km north of San Isidro Buensuceso) (Figure 1). SUs were placed in locations usually visited by mushroom collectors. This had the purpose to reproduce not the natural production of mushrooms but their real availability, since there is a strong competition among mushroom collectors. To reduce the impact of mushroom collection in our data, transects were always visited as early as possible.

The SUs were sampled at one week intervals during the rainy seasons (July to October). Both areas were visited during three years, from 1998 to 2000; SUs 1-4 (Southeast slope) were visited 40 times, and SUs 5-8 (Southwest slope) were visited 37 times. At each visit, all fruit bodies were counted, picked up, and weighed, to avoid double counting at the next visit. At least one sample of each species was taken to the laboratory, processed as a voucher specimen for identification, and deposited at TLXM herbarium.
Each SU was composed of two parallel transects of $250 \mathrm{~m}$ each. Both transects were separated by a $50 \mathrm{~m}$ distance. Transects were permanently marked every $5 \mathrm{~m}$, using sticks surrounded by black pieces of plastic on one side. We had a total of 100 sampling plots on each SU. Each plot had a radio of $1.13 \mathrm{~m}$ and a total area of $4.011 \mathrm{~m}^{2}[10]$. The total area sampled each year was of $3,200 \mathrm{~m}^{2}$.

Edibility of each species was determined through local information, literature from the area [3], literature from México [11], and literature from other parts of the world [12]. The complete list of the material reviewed was published previously by Montoya et al. [3].

2.3. Data Analysis. Species richness was determined by the number of species registered in each SU. Abundance of fruit bodies was defined as the number of fruit bodies of each species in each SU during the three-year period. Production was calculated as the total fresh weight of each species. Biomass was calculated by measuring the dry weight of each species (fruit bodies were dehydrated at least $24 \mathrm{~h}$ at $105^{\circ} \mathrm{C}$ ). Spatiotemporal frequency was calculated as the sum of the number of sampling plots where a species was found in each sampling date. Spatial frequency is the number of different plots in which a species was found during the three-year period in each SU. Spatial frequency was categorized in exponential classes: very infrequent (1-3), infrequent (4-9), frequent (10-21), very frequent (22-45), and extremely frequent (46-100). We looked for statistical differences in fruit body abundance and fruit body production between the two slopes. For this purpose, either the total number of fruit bodies or the total fresh weight in each SU (8) was considered as independent observations, while the data in each SU along the years (3) were considered as repeated measures, having twelve observations per slope. Means were compared by a bifactorial ANOVA for mixed designs in STATISTICA10 [13]. Availability of each species was determined by means of its ecological importance value, which equals the sum of its relative abundance, relative spatiotemporal frequency, and relative production [14].

Similarity between the SUs, according to their species composition, was computed using the species spatiotemporal frequency. A distance matrix was built, where rows corresponded to the species and columns to the eight SUs. The correlation index (Pearson product moment) was computed and SUs were clustered with the UPGMA method; then, the cophenetic value was computed. An ordination of the eight OTUs (=SUs) in a multidimensional space of characters was made by means of a Principal Component Analysis (PCA). Analyses were done in NTSYS-pc [15]. The diversity was calculated by using the Shannon-Wiener index. Since it is not possible to know the number of individuals, fruit bodies were counted and, instead of using abundance rates, spatiotemporal frequency was used. These analyses were done in the past software, version 2.16 [16].

\section{Results}

3.1. Species Richness. During the three sampling years, 61 edible mushroom species were found (Table 2): 48 species in 

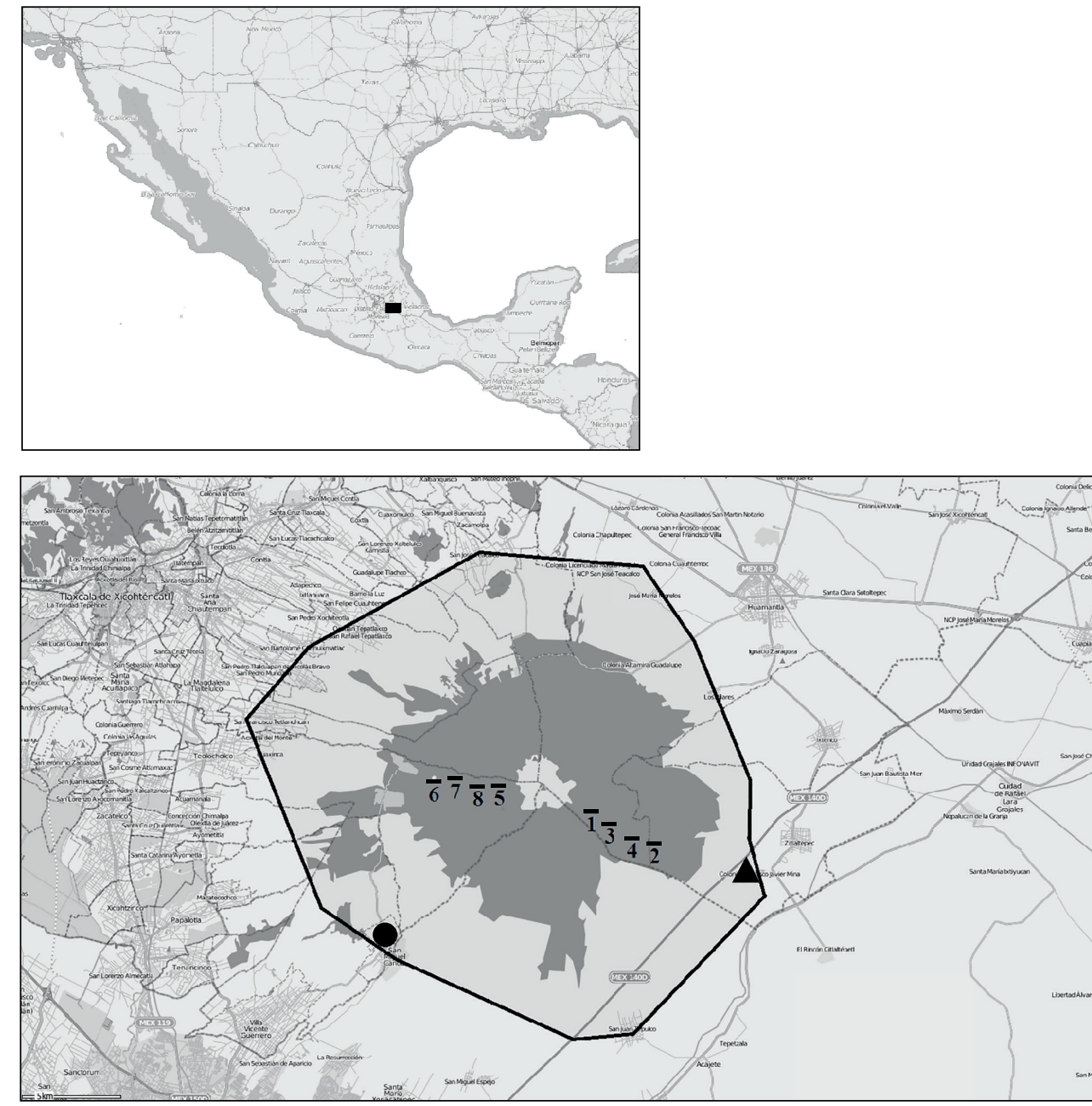

Location of the study area in Mexico

$\checkmark$ La Malinche National Park

- San Isidro Buensuceso
- Francisco Javier Mina

Forest area

- Sampling units 1-8

Figure 1: Map showing sampling units of La Malinche National Park, Tlaxcala, México, where the ecological data sampling of wild mushrooms was conducted.

the Southeast slope and 49 in Southwest slope. The species belonged to 37 genera. Fifty-one species were Basidiomycetes and the best represented families were Russulaceae with 9 species and Amanitaceae with 5 species. We identified 9 Ascomycetes, the family Helvellaceae being the best represented, with 4 species. 44 species were mycorrhizal, 15 were saprotrophs, and 2 were parasitic.

During the three years of sampling, the highest species richness was found in the Pinus-Abies forest (SU2 and SU6) and the lowest value was observed in the Pinus forest (SU7) of the Southwest slope. Despite the sampling year, the highest species richness was always observed in the Pinus-Abies forests (in 1998 at SU6; in 1999 at SU1 and SU5; in 2000 at SU5, SU6, and SU8). In 1999, a Pinus forest (SU3) located in the Southeast slope also showed a high species richness. The presence of different tree host species offers more possibilities to find a higher diversity of ectomycorrhizal mushrooms and more substrates for saprotrophic mushrooms. Likewise, microhabitats, produced by the soil humidity and mosses associated to Abies, produce several differences for the mushroom community.

Species exclusive to the Southeast slope were Amanita basii, Amanita vaginata, Armillaria aff. mellea, Cantharellus cibarius, Laccaria amethystina, Lyophyllum sp. 1, Ramaria sp. 1, Ramaria sp. 2, Ramaria sp. 3, Russula integra, and Russula olivacea. Species exclusive to the Southwest slope were Agaricus augustus, Amanita fulva, Boletus luridus, Clavulina cinerea, Clavulina coralloides, Geopora sp., Turbinellus floccosus, Helvella acetabula, Russula albonigra, Hygrophoropsis aurantiaca, Hygrophorus hypothejus, and Sarcosphaera coronaria.

3.2. Abundance of Fruit Bodies. During the three sampling years, the highest number of fruit bodies $(1,319)$ was found in 
TABLE 1: Geographic location of the sampling units selected for registering ecological data of wild edible mushrooms in La Malinche National Park, Tlaxcala, Mexico.

\begin{tabular}{|c|c|c|c|c|c|}
\hline \multirow{2}{*}{$\begin{array}{l}\text { Sampling } \\
\text { unit (SU) }\end{array}$} & \multirow{2}{*}{ Location } & \multirow{2}{*}{ Vegetation } & \multirow{2}{*}{$\begin{array}{l}\text { Altitude } \\
(\mathrm{p}=\text { plot })\end{array}$} & \multicolumn{2}{|c|}{ Geographical coordinates } \\
\hline & & & & North & West \\
\hline SU1 & $\begin{array}{l}7.5 \mathrm{~km} \text { east from } \\
\text { Francisco Javier } \\
\text { Mina }\end{array}$ & $\begin{array}{l}\text { Pinus montezumae-Abies religiosa forest. } 50 \\
\text { plots are located in Pinus and the other } 50 \text { in } \\
\text { Abies. Abies is located in a ravine. Pinus area } \\
\text { is subject to frequent harvesting of wild } \\
\text { mushrooms during the rainy season. }\end{array}$ & $\begin{array}{l}3263(\mathrm{p} 1) \\
3189(\mathrm{p} 50) \\
3260(\mathrm{p} 51) \\
3189(\mathrm{p} 100)\end{array}$ & $\begin{array}{l}19^{\circ} 12^{\prime} 17^{\prime \prime} \\
19^{\circ} 12^{\prime} 12^{\prime \prime} \\
19^{\circ} 12^{\prime} 11^{\prime \prime} \\
19^{\circ} 12^{\prime} 17^{\prime \prime}\end{array}$ & $\begin{array}{l}97^{\circ} 59^{\prime} 40^{\prime \prime} \\
97^{\circ} 59^{\prime} 25^{\prime \prime} \\
97^{\circ} 59^{\prime} 41^{\prime \prime} \\
97^{\circ} 59^{\prime} 26^{\prime \prime}\end{array}$ \\
\hline SU2 & $\begin{array}{l}4.5 \mathrm{~km} \text { east from } \\
\text { Francisco Javier } \\
\text { Mina }\end{array}$ & $\begin{array}{l}\text { P. montezumae-A. religiosa forest. } 50 \text { plots } \\
\text { are located in Pinus and the other } 50 \text { in } \\
\text { Abies. Abies is located in a ravine. Pinus area } \\
\text { is subject to frequent harvesting of wild } \\
\text { mushrooms and firewood during the rainy } \\
\text { season. }\end{array}$ & $\begin{array}{l}2900(\mathrm{p} 1) \\
2868(\mathrm{p} 50) \\
2898(\mathrm{p} 51) \\
2868(\mathrm{p} 100)\end{array}$ & $\begin{array}{l}19^{\circ} 12^{\prime} 09^{\prime \prime} \\
19^{\circ} 12^{\prime} 08^{\prime \prime} \\
19^{\circ} 12^{\prime} 14^{\prime \prime} \\
19^{\circ} 12^{\prime} 13^{\prime \prime}\end{array}$ & $\begin{array}{l}97^{\circ} 57^{\prime} 47^{\prime \prime} \\
97^{\circ} 57^{\prime} 31^{\prime \prime} \\
97^{\circ} 57^{\prime} 48^{\prime \prime} \\
97^{\circ} 57^{\prime} 33^{\prime \prime}\end{array}$ \\
\hline SU3 & $\begin{array}{l}7 \mathrm{~km} \text { east from } \\
\text { Francisco Javier } \\
\text { Mina }\end{array}$ & $\begin{array}{l}\text { P. montezumae forest. The forest is subject to } \\
\text { frequent harvesting of wild mushrooms and } \\
\text { firewood during the rainy season. }\end{array}$ & $\begin{array}{c}3146(\mathrm{p} 1) \\
3104(\mathrm{p} 50) \\
3139(\mathrm{p} 51) \\
3097(\mathrm{p} 100)\end{array}$ & $\begin{array}{l}19^{\circ} 12^{\prime} 05^{\prime \prime} \\
19^{\circ} 11^{\prime} 59^{\prime \prime} \\
19^{\circ} 12^{\prime} 00^{\prime \prime} \\
19^{\circ} 11^{\prime} 54^{\prime \prime}\end{array}$ & $\begin{array}{l}97^{\circ} 59^{\prime} 15^{\prime \prime} \\
97^{\circ} 59^{\prime} 03^{\prime \prime} \\
97^{\circ} 59^{\prime} 16^{\prime \prime} \\
97^{\circ} 59^{\prime} 04^{\prime \prime}\end{array}$ \\
\hline SU4 & $\begin{array}{l}5.5 \mathrm{~km} \text { east from } \\
\text { Francisco Javier } \\
\text { Mina }\end{array}$ & $\begin{array}{l}\text { P. montezumae forest. The forest is subject to } \\
\text { frequent harvesting of wild mushrooms } \\
\text { during the rainy season. }\end{array}$ & $\begin{array}{l}2996(\mathrm{p} 1) \\
2951(\mathrm{p} 50) \\
2989(\mathrm{p} 51) \\
2954(\mathrm{p} 100)\end{array}$ & $\begin{array}{l}19^{\circ} 12^{\prime} 00^{\prime \prime} \\
19^{\circ} 11^{\prime} 58^{\prime \prime} \\
19^{\circ} 11^{\prime} 55^{\prime \prime} \\
19^{\circ} 11^{\prime} 52^{\prime \prime}\end{array}$ & $\begin{array}{l}97^{\circ} 58^{\prime} 28^{\prime \prime} \\
97^{\circ} 58^{\prime} 13^{\prime \prime} \\
97^{\circ} 58^{\prime} 29^{\prime \prime} \\
97^{\circ} 58^{\prime} 15^{\prime \prime}\end{array}$ \\
\hline SU5 & $\begin{array}{l}14.5 \mathrm{~km} \text { west from } \\
\text { San Luis } \\
\text { Teolocholco }\end{array}$ & $\begin{array}{l}\text { A. religiosa forest. The forest is subject to } \\
\text { frequent tree cutting. }\end{array}$ & $\begin{array}{c}3600(\mathrm{p} 1) \\
3660(\mathrm{p} 50) \\
3390(\mathrm{p} 51) \\
3540(\mathrm{p} 100)\end{array}$ & $\begin{array}{l}19^{\circ} 13^{\prime} 49^{\prime \prime} \\
19^{\circ} 13^{\prime} 57^{\prime \prime} \\
19^{\circ} 13^{\prime} 55^{\prime \prime} \\
19^{\circ} 13^{\prime} 52^{\prime \prime}\end{array}$ & $\begin{array}{l}98^{\circ} 03^{\prime} 28^{\prime \prime} \\
98^{\circ} 03^{\prime} 35^{\prime \prime} \\
98^{\circ} 03^{\prime} 36^{\prime \prime} \\
98^{\circ} 03^{\prime} 25^{\prime \prime}\end{array}$ \\
\hline SU6 & $\begin{array}{l}11.5 \mathrm{~km} \text { west from } \\
\text { San Luis } \\
\text { Teolocholco }\end{array}$ & $\begin{array}{l}\text { A. religiosa forest with some individuals of } P \text {. } \\
\text { montezumae and Salix sp. }\end{array}$ & $\begin{array}{c}3111(\mathrm{p} 1) \\
3134(\mathrm{p} 50) \\
3116(\mathrm{p} 51) \\
3154(\mathrm{p} 100)\end{array}$ & $\begin{array}{l}19^{\circ} 13^{\prime} 58^{\prime \prime} \\
19^{\circ} 14^{\prime} 02^{\prime \prime} \\
19^{\circ} 13^{\prime} 56^{\prime \prime} \\
19^{\circ} 14^{\prime} 01^{\prime \prime}\end{array}$ & $\begin{array}{l}98^{\circ} 05^{\prime} 05^{\prime \prime} \\
98^{\circ} 04^{\prime} 57^{\prime \prime} \\
98^{\circ} 05^{\prime} 06^{\prime \prime} \\
98^{\circ} 04^{\prime} 56^{\prime \prime}\end{array}$ \\
\hline SU7 & $\begin{array}{l}12 \mathrm{~km} \text { west from } \\
\text { San Luis } \\
\text { Teolocholco }\end{array}$ & $\begin{array}{l}\text { Open forest dominated by } P \text {. montezumae. } \\
\text { The forest is subject to frequent tree cutting. }\end{array}$ & $\begin{array}{c}3150(\mathrm{p} 1) \\
3330(\mathrm{p} 50) \\
3240(\mathrm{p} 51) \\
3330(\mathrm{p} 100)\end{array}$ & $\begin{array}{l}19^{\circ} 13^{\prime} 50^{\prime \prime} \\
19^{\circ} 13^{\prime} 50^{\prime \prime} \\
19^{\circ} 13^{\prime} 51^{\prime \prime} \\
19^{\circ} 13^{\prime} 49^{\prime \prime}\end{array}$ & $\begin{array}{l}98^{\circ} 04^{\prime} 00^{\prime \prime} \\
98^{\circ} 04^{\prime} 08^{\prime \prime} \\
98^{\circ} 04^{\prime} 07^{\prime \prime} \\
98^{\circ} 03^{\prime} 58^{\prime \prime}\end{array}$ \\
\hline SU8 & $\begin{array}{l}13 \mathrm{~km} \text { west from } \\
\text { San Luis } \\
\text { Teolocholco }\end{array}$ & $\begin{array}{l}\text { Mixed forest dominated by } P \text {. montezumae } \\
\text { mixed with Alnus jorullensis, A. religiosa, } \\
\text { and Salix sp. The forest is subject to frequent } \\
\text { tree cutting. }\end{array}$ & $\begin{array}{c}3315(\mathrm{p} 1) \\
3269(\mathrm{p} 50) \\
3316(\mathrm{p} 51) \\
3270(\mathrm{p} 100)\end{array}$ & $\begin{array}{l}19^{\circ} 13^{\prime} 54^{\prime \prime} \\
19^{\circ} 13^{\prime} 55^{\prime \prime} \\
19^{\circ} 13^{\prime} 51^{\prime \prime} \\
19^{\circ} 13^{\prime} 51^{\prime \prime}\end{array}$ & $\begin{array}{l}98^{\circ} 04^{\prime} 02^{\prime \prime} \\
98^{\circ} 04^{\prime} 13^{\prime \prime} \\
98^{\circ} 04^{\prime} 01^{\prime \prime} \\
98^{\circ} 04^{\prime} 14^{\prime \prime}\end{array}$ \\
\hline
\end{tabular}

(For an integer $(n)$, SUn $=$ sampling unit $n$ and $\mathrm{p} n=\operatorname{plot} n$.)

the SU4, in a Pinus forest on Southeast slope. This means that they were 5.6 times more than those recorded at SU1, where the less number of fruit bodies was found (230). The lowest abundance was observed in the Pinus-Abies forest (SU1) of the same area. More fruit bodies were found in the year 2000 than in the two previous years. Southeast slope produced almost twice as many fruit bodies as the Southwest slope (Table 2). The most abundant species in the three years were L. trichodermophora, Hebeloma mesophaeum, Clitocybe gibba, Helvella lacunosa, Morchella elata, Suillus pseudobrevipes, Helvella crispa, and S. coronaria.

Although the mean of fruit bodies produced in the Southeast slope (256.83 fruit bodies/SU year) doubled those produced in the Southwest slope (114.42 fruit bodies/SU year), no statistical differences were found between slopes $\left(F_{(1,18)}=\right.$ $3.77, P=0.06)$, nor between years $\left(F_{(2,18)}=0.291, P=\right.$ $0.750)$, because of the high standard deviation in the data of Southeast slope (233.882). The interaction between slopes and years also showed any difference $\left(F_{(2,18)}=1.034, P=0.375\right)$.
3.3. Production. Comparing the values obtained for the two areas, higher values $\left(16.10 \mathrm{Kg} / 3200 \mathrm{~m}^{2}\right)$ were found on the Southeast slope, L. trichodermophora being the most productive species, whereas, on the Southwest slope $(13.44 \mathrm{Kg} /$ $3200 \mathrm{~m}^{2}$ ), S. coronaria showed the highest values. The total fresh weight recorded at the SUs during the three-year period was $29.54 \mathrm{Kg} / 3200 \mathrm{~m}^{2}$ (Table 2). This amount means $92.10 \mathrm{Kg} / \mathrm{ha} / 3$ years of edible wild mushrooms. SU3, located in a Pinus forest, had the highest values of fresh weight. Year 2000 had the greatest production of edible mushroom fresh weight.

The species with the highest values of fresh weight were in 1998 L. ovispora, R. acrifolia, R. brevipes, H. mesophaeum, and L. trichodermophora; in 1999 L. trichodermophora, R. brevipes, R. acrifolia, and A. rubescens; and in year 2000 S. coronaria, $L$. trichodermophora, S. pseudobrevipes, R. acrifolia, C. glaucopus, and B. pinophilus. No statistical differences were found between the means of fresh weight of edible mushrooms produced in each slope $\left(F_{(1,18)}=0.417, P=0.526\right)$ nor 


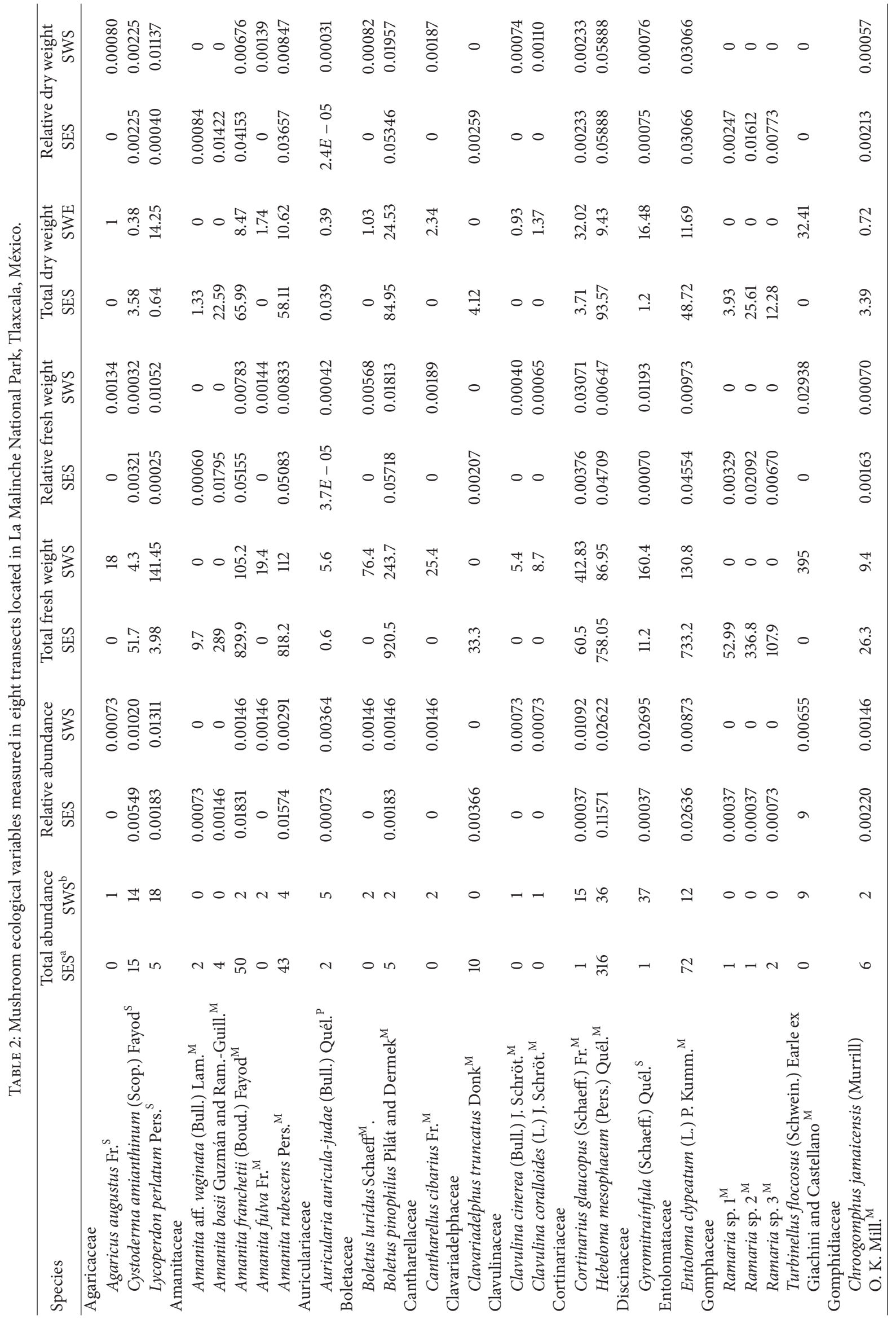




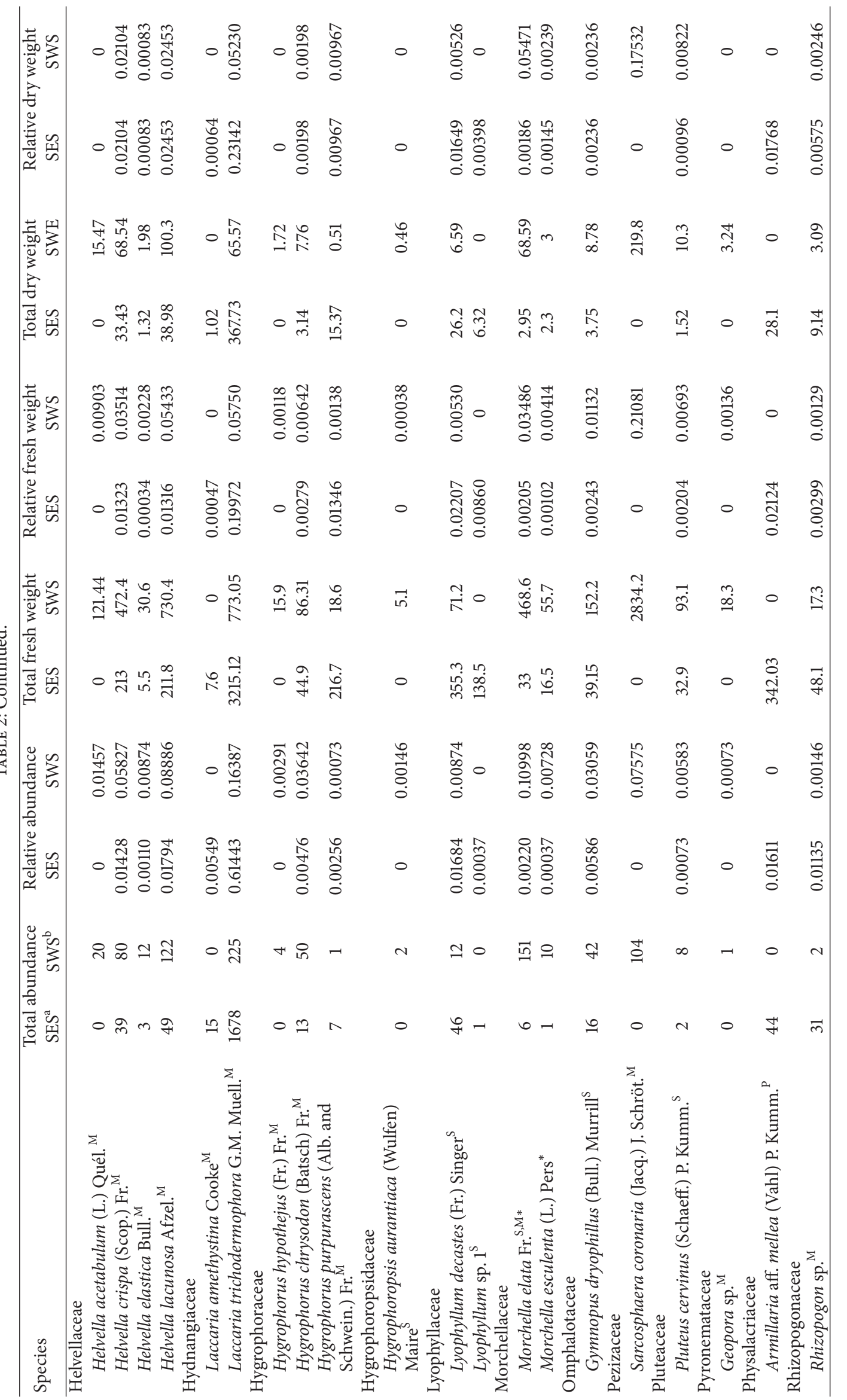




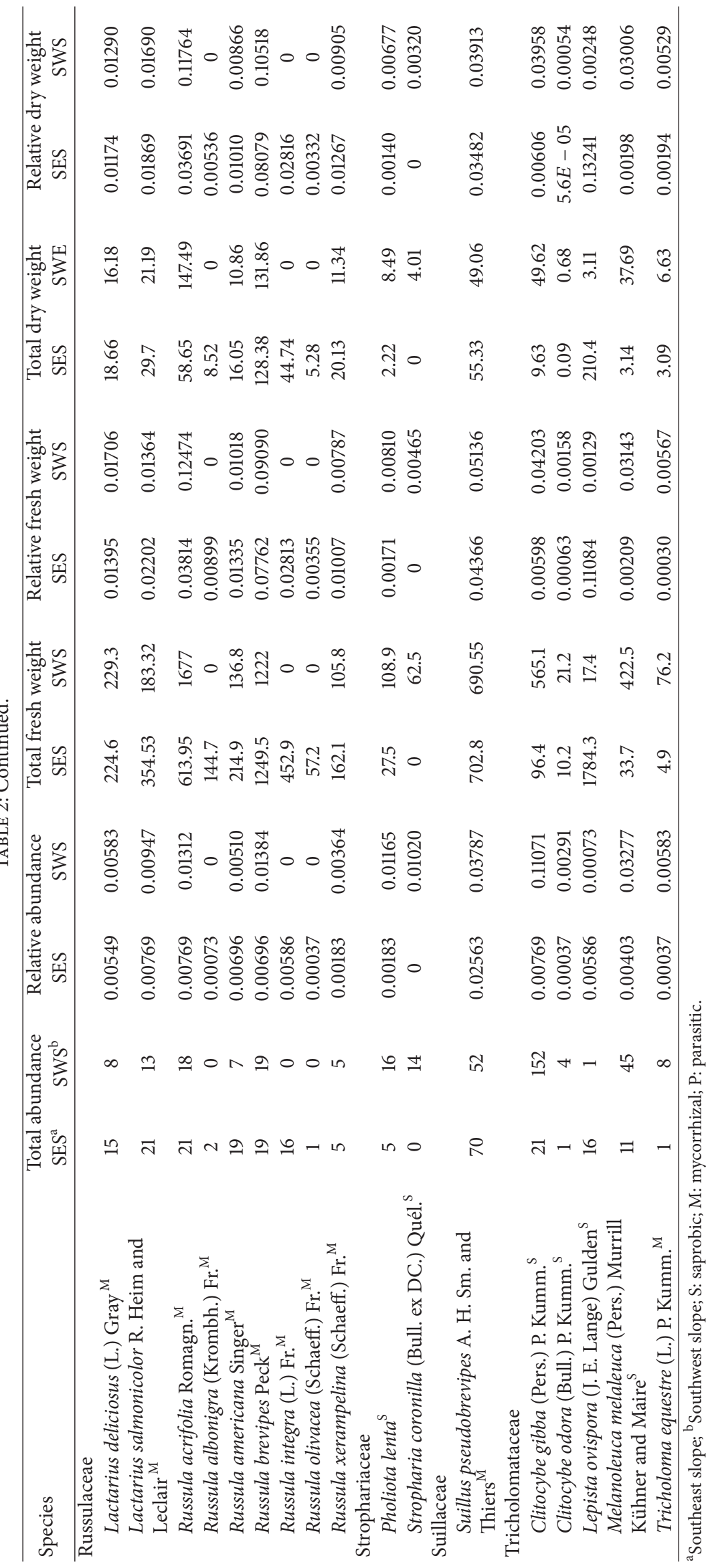


between the years $\left(F_{(2,18)}=2.24, P=0.135\right)$. The interaction between mushrooms abundance by slopes and years did not show any difference $\left(F_{(2,18)}=1.19, P=0.325\right)$.

3.4. Biomass. The highest biomass production $(1.59 \mathrm{Kg} /$ $3200 \mathrm{~m}^{2} / 3$ years) was recorded in the SUs located in Southeast slope, while $1.25 \mathrm{Kg} / 3200 \mathrm{~m}^{2} / 3$ years was produced in the Southwest slope. L. trichodermophora and L. ovispora were the species with the highest biomass production values in the Southeast slope and S. coronaria and $R$. brevipes in the Southwest slope. The total biomass was $2.84 \mathrm{Kg} / 3200 \mathrm{~m}^{2} / 3$ years, which would mean $8.87 \mathrm{~kg} / \mathrm{ha}$. SU3 had the highest values. The highest values were recorded in year 2000 (Table 2).

3.5. Spatiotemporal Frequency. Southeast slope had a higher spatiotemporal frequency (STF), presenting 905 plots with mushrooms, while Southwest slope had 590 plots with mushrooms. SU4, located in a Pinus forest, had the highest overall STF with 371, while SU7, also in a Pinus forest, had the lowest with 96 . Year 2000 had the highest overall STF with 642 plots. The species observed in the biggest number of sampling plots were $L$. trichodermophora, $H$. mesophaeum, $H$. lacunosa, $H$. crispa, S. pseudobrevipes, and C. gibba; then, they were the species most widely distributed in the study area (Table 3 ).

3.6. Spatial Frequency. Southeast slope had the highest spatial frequency (SF) (471 plots) and Southwest slope showed a relative SF of 389 plots. The SUs with the highest values of frequency were SU4, SU3, SU6, and SU5. SU7 presented the lowest SF. Species with the highest percentage of SF throughout all the sampled area were L. trichodermophora $(17.75 \%), H$. mesophaeum (9.00\%), H. lacunosa (8.00\%), H. crispa (6.38\%), M. melaleuca (4.38\%), S. pseudobrevipes (4.25\%), and C. gibba (4.13\%) (Table 3).

The SF values for A. basii, A. rubescens, B. pinophilus, $H$. mesophaeum, L. trichodermophora, and L. decastes were higher in the Southeast slope, while, for T. floccosus, H. crispa, H. lacunosa, M. elata, and M. esculenta, higher SFs were registered in the Southwest slope. In both cases, those species have been determined to be the most important from a cultural perspective [5].

3.7. Availability. Values obtained as the availability index for each species are showed in Table 3. Species with the highest values in this study were $L$. trichodermophora, S. coronaria, $H$. lacunosa, H. crispa, M. elata, C. gibba, M. melaleuca, $R$. acrifolia, $R$. brevipes, and $S$. pseudobrevipes. The information obtained from the availability index shows the presence of several different environments adequate for the fruiting of mushrooms. In the Southwest slope, Abies forests are located in a lower altitude than those in the Southeast slope, where Pinus forests are predominant, so there are differences in species between the two sites.

L. trichodermophora, H. mesophaeum, E. clypeatum, and $S$. pseudobrevipes had the highest values in the Southeast slope, while $L$. trichodermophora, S. coronaria, H. lacunosa, C. gibba, and $H$. crispa had the highest values on the Southwest slope. As for the Southwest slope, Figure 2 shows a greater diversity of species with considerable availability. These were present in space and time in a differential way. As well as in the Southeast slope (Figure 3), the significance of L. trichodermophora stands out. In this case, $S$. coronaria, because of its consistency, showed high production values considering its low abundance.

The availability of species measured by the ecological importance value did show remarkable differences between the two slopes. The Southeast slope has two dominant species: $L$. trichodermophora and H. mesophaeum. The other species registered on this area showed low values, suggesting their scarce availability in the three sampling years. L. trichodermophora was very abundant; it was widely distributed in the said space and time. In contrast, its production was not very high because of the size of its fruit bodies. It is interesting to notice that mushrooms as $B$. pinophilus have relatively high values of production due to the consistence and size of their fruit bodies, despite their low abundance and distribution in time and space. These characteristics contribute to the increase of the high production values in the Southeast slope.

3.8. Similarity. The cluster analysis (Figure 4) shows the similarity between SUs based on the values of the spatiotemporal frequency of species. Two main clusters can be observed. The first is composed of three SUs, two from the Southwest slope (SU6, SU8) and one from the Southeast slope (SU1). The two most similar SUs of this group are SU1 and SU6 and are related to SU8; half of SU1 and all SU6 are located in an Abies forest and SU8 which is the most different SU is in a mixed forest. The second cluster includes SU2, SU4, SU7, and SU3, three of them from the Southeast slope, and SU7 is from the Southwest slope, all of which are set up on Pinus forests. SU2 and SU4 are the two most similar. SU3 is the most different within this group. SU5 is the most different of all SUs.

As shown in Figure 5, the results of PCA provide a sharper definition of the different clusters described above. The results of PCA indicate that the species that contributed to cluster formation (which have a loading $>0.7$ on the first two PCs) were $M$. aff. melaleuca, L. trichodermophora, A. basii, H. mesophaeum, C. cibarius, and C. amianthinum in PC1. A. vaginata, Geopora sp., G. dryophilus, G. infula, M. elata, and S. coronaria in PC2 are all absent from SU3. The first two Principal Components explain cumulatively $44.9 \%$ of data variation.

The representation of the OTUs in a three-dimensional space of characters (Figure 5) shows that SUs studied are closer to one another by vegetation type. In the clusters formed by these SUs, it is possible to identify subgroups, according to the species of edible mushrooms present or absent. Sampling units 1 and 6 showed 17 species in common, some are characteristic of Abies forests, for example, C. gibba, C. odora, H. crispa, H. elastica, H. lacunosa, L. salmonicolor, and M. esculenta. And some others also grow in Pinus forests, for example, A. rubescens and E. clypeatum. SU8 presented six exclusive species, which had the highest values in the analysis of PCA. Conforming a subgroup distinct from the previous, SUs 2 and 4 presented 19 species in common, most of them are mushrooms associated with Pinus forests (e.g., A. basii, A. franchetii, H. mesophaeum, L. trichodermophora, and S. pseudobrevipes, among others), and SUs 3 and 7 share 16 species 


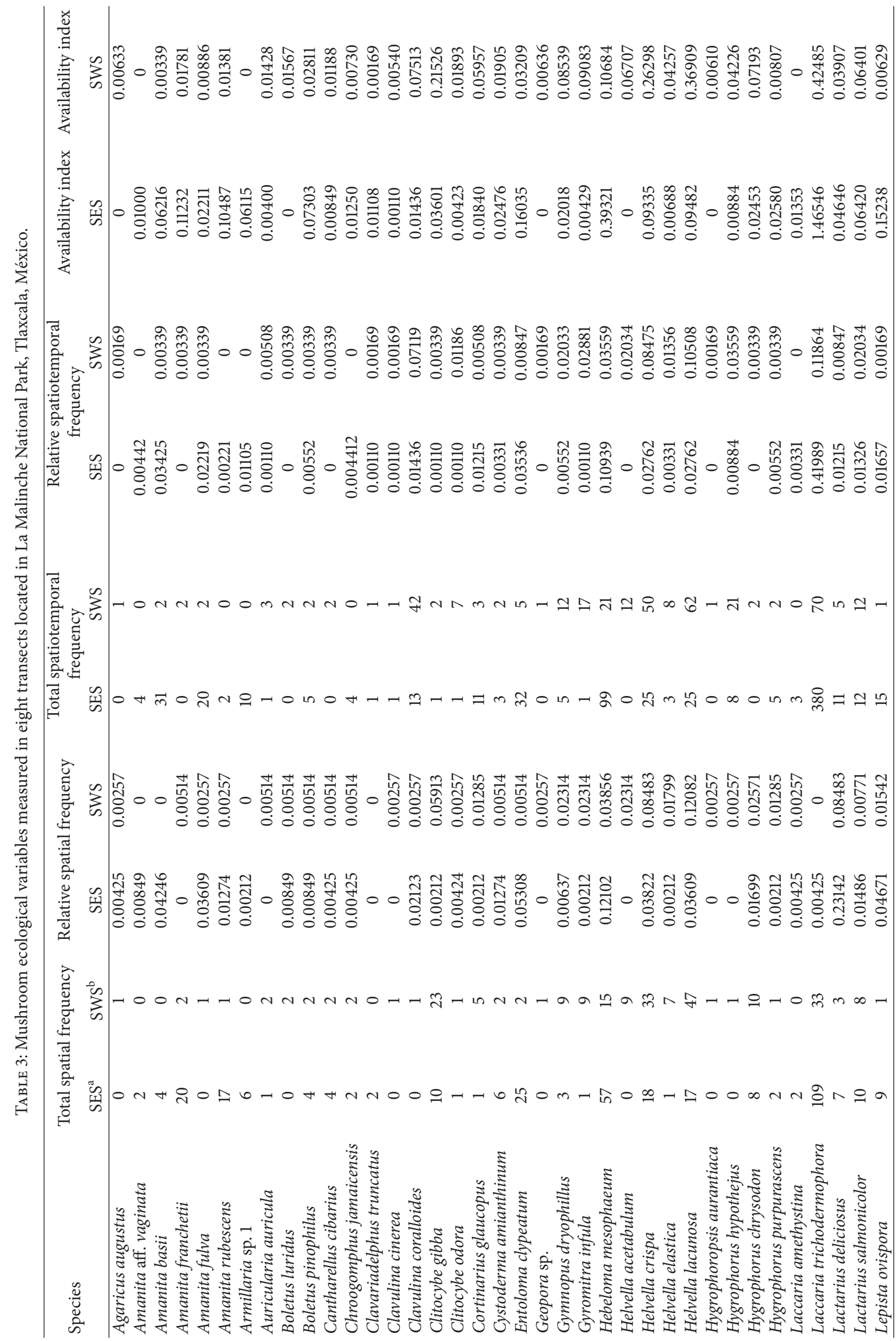




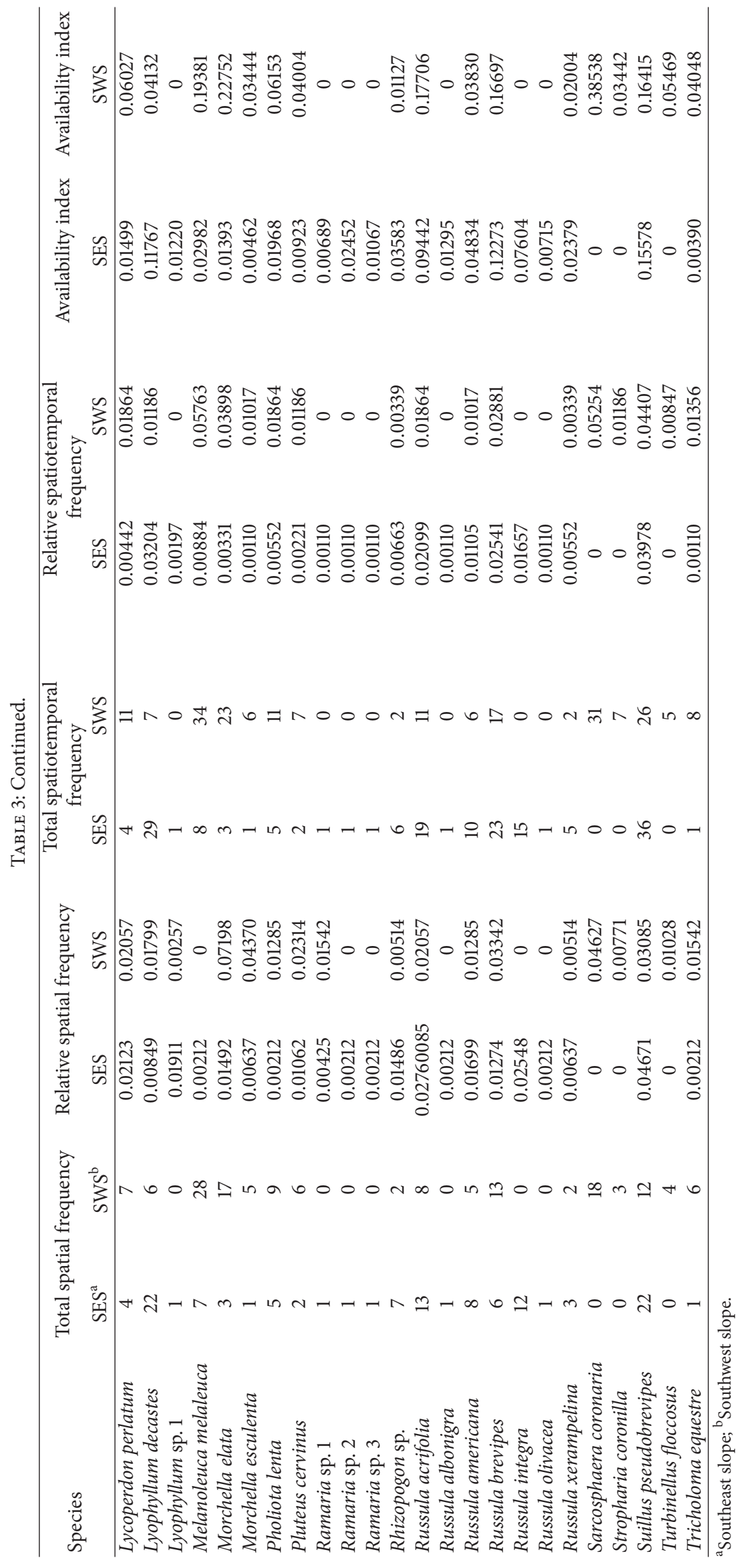




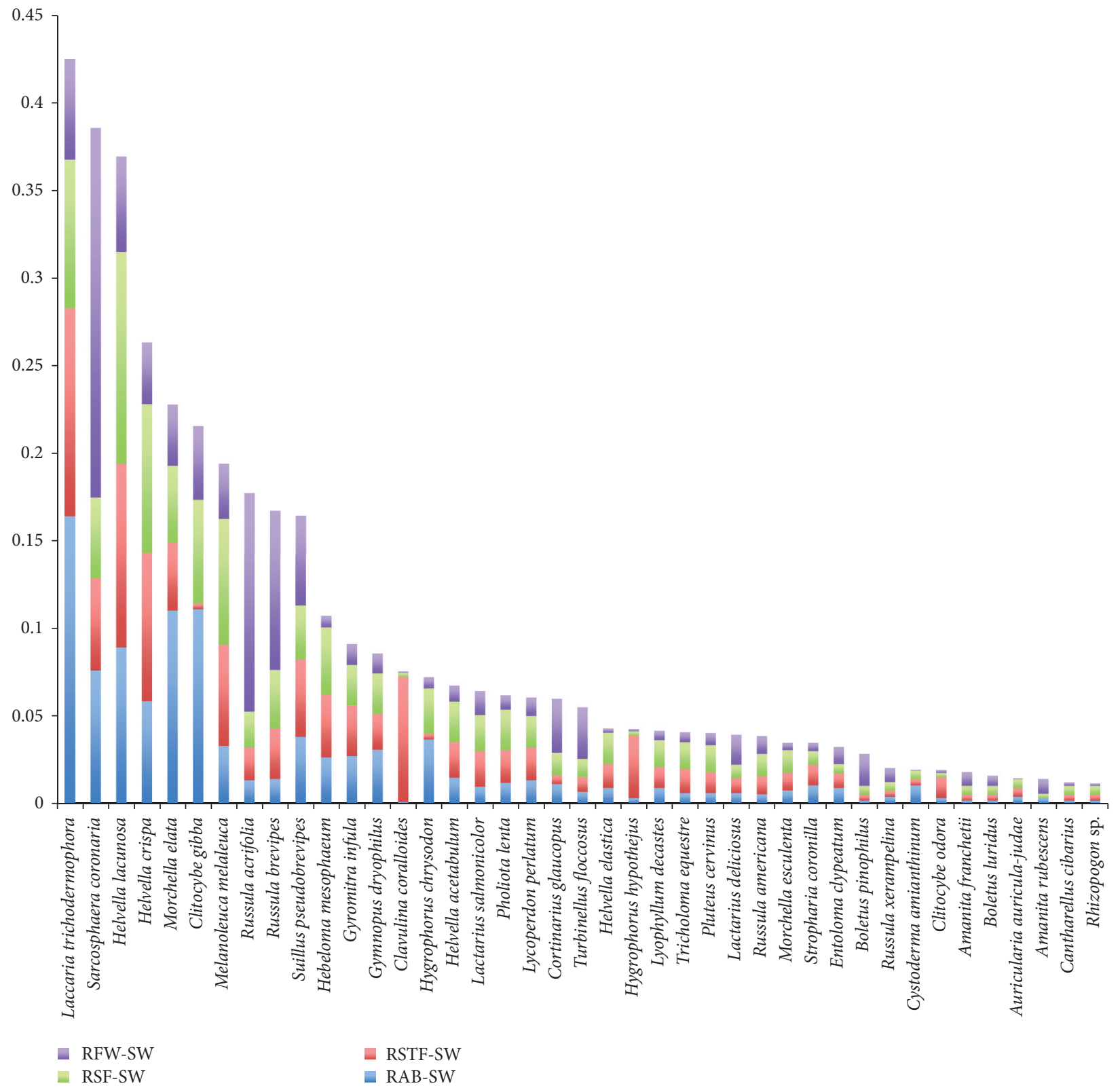

Figure 2: Availability of wild edible mushrooms in Southwest slope of La Malinche National Park, México. Availability Index was obtained by adding the relative values of abundance, spatial frequency, spatiotemporal frequency, and fresh weight of each mushroom species. RFW-SW: relative fresh weight of Southwest slope; RSF-SW: relative spatial frequency of Southwest slope; RSTF-SW: relative spatiotemporal frequency of Southwest slope; RAB-SW: relative abundance of Southwest slope.

which are mushrooms associated with Pinus forests (e.g., A. franchetii and B. pinophilus). SU 5 was the most different; it had two exclusive species (Geopora sp. and S. coronaria) and is located higher in altitude than other SUs.

Comparing information obtained for both slopes of $\mathrm{La}$ Malinche National Park, the highest values, in all parameters considered, were observed in the Southeast slope. However, we did not find statistical differences.

3.9. Diversity. Based on the abundance of fruit bodies, the Shannon-Wiener diversity index $\left(H^{\prime}\right)$ in the Southeast slope was 1.78 , with a $\max H^{\prime}$ of $3.87 . H^{\prime}$ in Southwest slope was 3.00 , with a max $3.89 H^{\prime}$. Based on the abundance of plots, $H^{\prime}$ was 2.53 for Southeast slope and 3.26 for Southwest slope. In summary, considering the abundance of fruit bodies or plots, the greatest diversity values were found in the Southwest. The calculation of the weighted diversity index $\left(H_{p}\right)$ showed that both slopes are statistically different with respect to one another (Table 4).

The highest value for the Shannon-Wiener diversity index was obtained in SU7 $\left(H^{\prime}=3.43\right)$ located in the Southwest slope, with 21 species. The lowest value of diversity was 
TABle 4: Wild edible mushrooms diversity in La Malinche National Park, Mexico.

\begin{tabular}{|c|c|c|c|c|}
\hline & \multicolumn{2}{|c|}{ Abundance of fruit bodies } & \multicolumn{2}{|c|}{ Abundance of plots } \\
\hline & Southwest slope & Southeast slope & Southwest slope & Southeast slope \\
\hline$S=$ species richness & 49 & 48 & 49 & 48 \\
\hline$N=$ number of fruit bodies/plots & 1373 & 2731 & 590 & 903 \\
\hline$H^{\prime}=$ Shannon-Wiener diversity & 3.00 & 1.78 & 3.26 & 2.55 \\
\hline$H_{\max }^{\prime}=$ maximum diversity & 3.89 & 3.87 & 3.89 & 3.87 \\
\hline$H_{p}=$ weighted diversity & 2.98 & 1.77 & 3.22 & 2.50 \\
\hline Var $=$ variance & 0.000930 & 0.001224 & 0.00173 & 0.00296 \\
\hline$t=$ Student's $t$-test & \multicolumn{2}{|c|}{-26.055} & \multicolumn{2}{|c|}{-10.573} \\
\hline $\mathrm{df}=$ degree of freedom & \multicolumn{2}{|c|}{3937.4} & \multicolumn{2}{|c|}{1488.8} \\
\hline$P($ same $)=$ probability & \multicolumn{2}{|c|}{$3.3256 e^{188}$} & \multicolumn{2}{|c|}{$3.0487 e^{25}$} \\
\hline
\end{tabular}

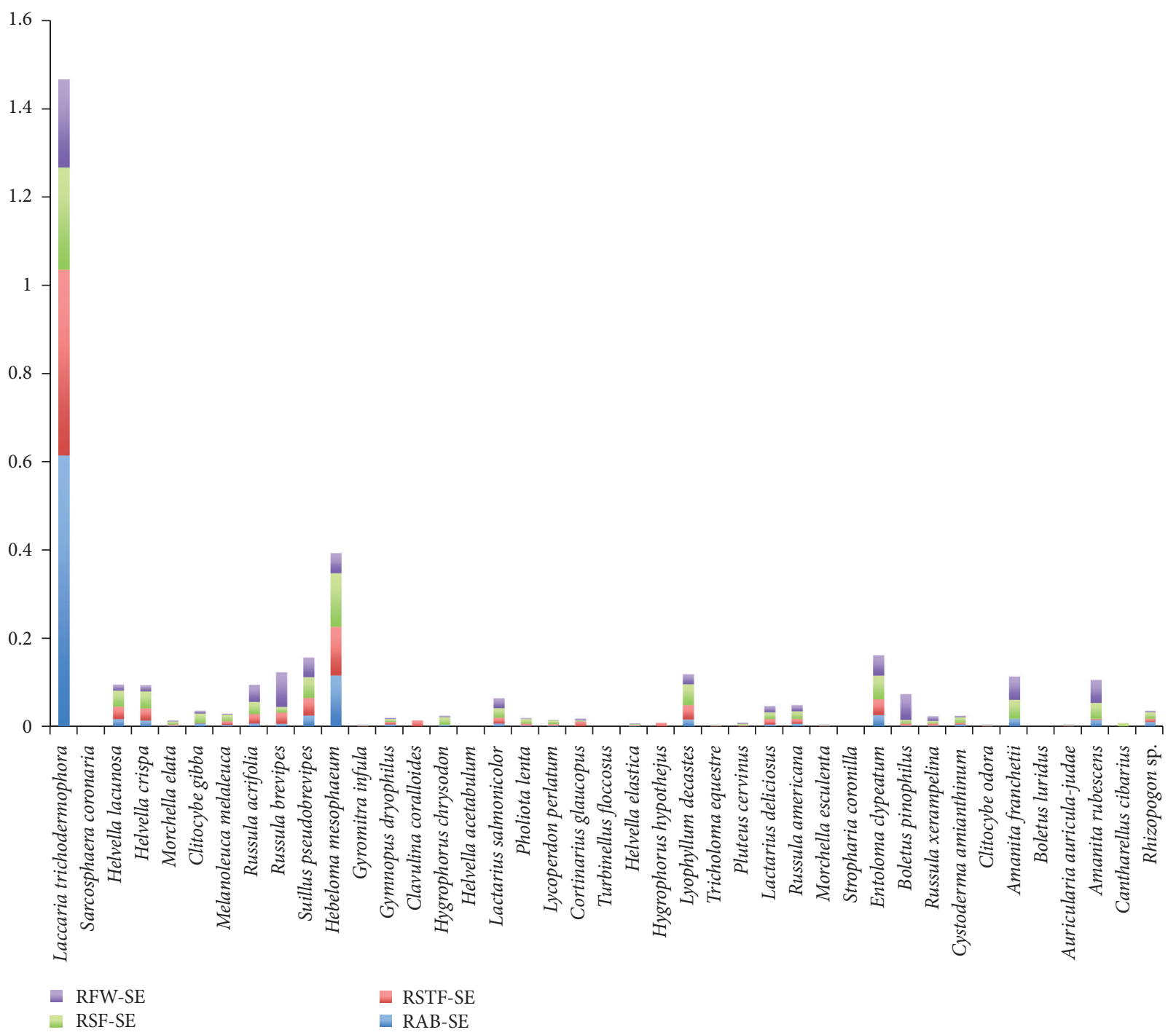

FIGURE 3: Availability of wild edible mushrooms in Southeast slope of La Malinche National Park, México. Availability Index was obtained by adding the relative values of abundance, spatial frequency, spatiotemporal frequency, and fresh weight of each mushroom species. RFW-SE: relative fresh weight of Southeast slope; RSF: relative spatial frequency of Southeast slope; RSTF-SE: relative spatiotemporal frequency of Southeast slope; RAB-SE: relative abundance of Southeast slope. 


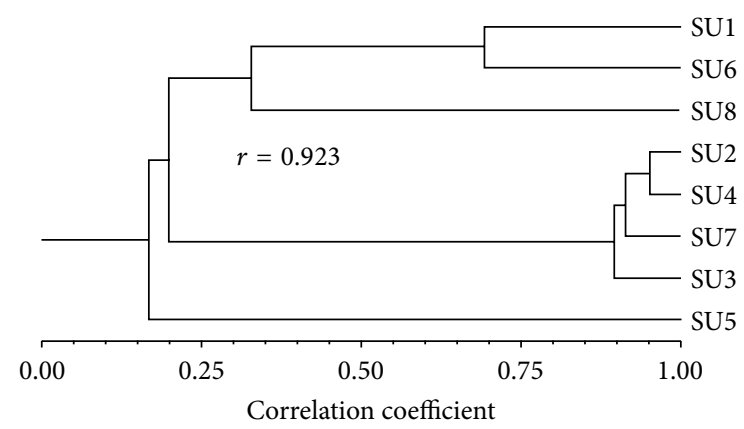

FIGURE 4: Phenogram showing the similarity between SUs located in La Malinche National Park, Mexico, according to spatiotemporal frequency of species of wild edible mushrooms. SUs 1 and 2 are located in Abies-Pinus forests (50 plots in Abies and 50 in Pinus). SUs 5 and 6 are located in Abies-Pinus forests. SUs 3, 4, and 7 are located in Pinus forests. SU 8 is located in a mixed forest.

obtained in SU4 $\left(H^{\prime}=1.81\right)$ located in the Southeast slope, with 25 species. The evenness ranged from 0.88 in SU1 (PinusAbies forest) to 0.78 in SU8 (mixed forest dominated by Pinus) (Table 4).

\section{Discussion}

The area located in Southeast slope of La Malinche National Park presented the highest values of abundance, production, biomass, STF, and SF of fruiting bodies of edible wild mushrooms, while the values obtained in the SUs located in the Southwest slopes were lower. Southeast slope is an area influenced by mestizo communities, contrary to the indigenous condition in the Southwest region; this is a relevant fact in terms of forest management. The other difference between both slopes, related to the management of mushrooms, is the level of commercialization, which is made in great scale in some communities of the Southeast slope, for example, in Javier Mina, opposite to the Southwest region, where there exists a low-level trade of mushrooms, and in San Isidro Buensuceso, where their use is mainly for self-consumption. By this way, different extractive techniques and uses have different impacts on the availability of mushrooms in the forest areas surrounding the communities [5].

Both locations had almost the same number of species. In year 2000, higher values were found in all variables measured. With regard to the SUs, the highest values were recorded for SU4 and the lowest for SU1. Highest values in production (fresh weight) and biomass (dry weight) were recorded in SU3. Highest species richness was detected in SUs 2 and 6. Largest number of exclusive species was found in SU8 and SU2. Mycorrhizal fungi were more abundant than saprobes, since families with more species observed were Russulaceae, Tricholomataceae, Amanitaceae, Gomphaceae, and Helvellaceae.

It should be noticed that $H$. mesophaeum and M. elata had their highest abundance in 1998; this was probably a result of the fires before the rainy season. Fires had a favorable effect in stimulating fruiting and in increasing the number of sporocarps. Moser [17] mentions the carbonicolous habit of $H$.

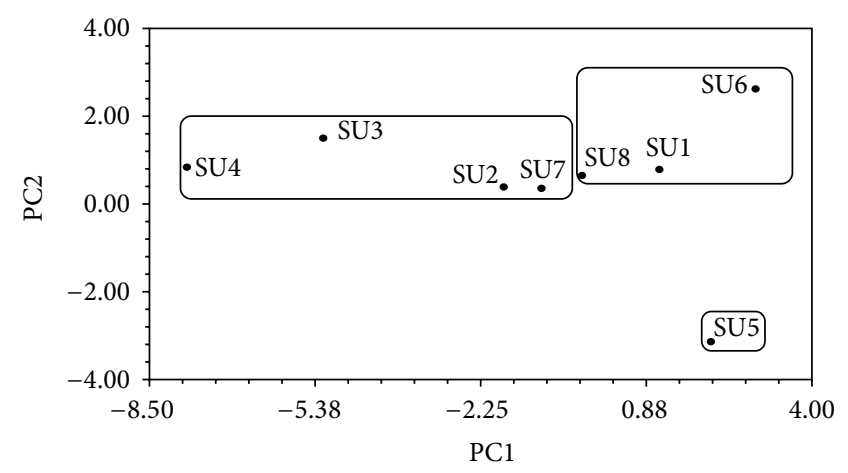

FIGURE 5: Representation of the sampling units in La Malinche National Park, in a bidimensional space of characters, with a Principal Component Analysis. Sampling units (SUs) from 1 to 8 are grouped (inside rectangles) according to the spatiotemporal frequency of edible mushrooms growing in each one. Principal Component (PC) 1 versus PC 2. The first two Principal Components explain cumulatively $44.9 \%$ of data variation.

mesophaeum, and Lincoff et al. [18] describe the preference of M. elata to fruit in areas that have been burned prior to the rainy season. That is the reason why such species presented high values of abundance during the three years of sampling. M. elata was collected from the Pinus-Abies forest (SUs 1, 5, and 8 ) and H. mesophaeum from both Pinus and Pinus-Abies forests (SUs 1-8).

Most significant species in the Southeast slope have the highest values in production, abundance, and spatial frequency in this area, compared to the same species in the other slope. The same behavior was observed in the Southwest slope. Then, the possibility to make a more comprehensive research is suggested, that takes into consideration the monitoring of ecology of mushrooms for a long period, including the measurement of structural characteristics of vegetation and weather variables. It would also be very important to include the measurement of the impact of harvesting and other traditional management practices as ecological variables. Intentional fires increase the production of some species as $H$. mesophaeum and Morchella spp., but there is no information of their effect on other species in the area.

Investigations made about the ecology of wild edible fungi in Mexico have used different methods, cannot make any kind of comparisons. However in some forests of Central and Southern Mexico, production values obtained are very variable compared to the present study. We recorded $29.53 \mathrm{~kg} / 3200 \mathrm{~m}^{2}$, or $92.101 \mathrm{~kg} / \mathrm{ha} / 3$ years, and Zamora-Martínez and Nieto de Pascual-Pola [19] reported a production of $76.3 \mathrm{~kg} / \mathrm{ha} /$ year and, for the other year, $52.4 \mathrm{~kg} / \mathrm{ha}$ of edible wild mushrooms in a Christmas trees plantation (Abies religiosa) in Topilejo, Mexico. The authors suggest that the annual variations in the production of mushrooms were due to temperature and precipitation, as well as the age of the trees. Also, in the Malinche Volcano, Hernández-Díaz [8] assessed the production of wild edible mushrooms in a pine and fir forest, sampling two permanent plots of $900 \mathrm{~m}^{2}$ each. There were 35 species of fungi: 28 in fir and 22 in pine. 
The total production was $55.50 \mathrm{~kg} / \mathrm{ha} /$ year of weight fresh. Anahid [20] reported 49 species of wild edible mushrooms in the fir forest of La Malinche volcano, with a production of $27.34 \mathrm{~kg} / \mathrm{ha} /$ year.

Garibay-Orijel et al. [14] recorded 81 species of wild edible mushrooms in the pine-oak forest of Ixtlan de Juárez, Oaxaca. The production was of $59.01 \mathrm{~kg} / 105,600 \mathrm{~m}^{2}$ or $5.58 \mathrm{~kg} / \mathrm{ha} / 2$ years. Availability is very heterogeneous in dense areas within the same forest. Species composition is very different, abundance and production are contrasting. This was not the case with La Malinche where the species composition in both slopes compared was very similar, and the availability of species shows two patterns, few available species in Southeast slope and greater availability of many species in Southwest slope. Both in Ixtlan and in La Malinche, L. trichodermofora is one of the most abundant species. Garibay-Orijel et al. [14] suggest that the utilization of the species must be done using different strategies taking into account their availability.

It is necessary to remark the importance of designing an ecological method more adequate to sample mushroom species. Because of the way that data were obtained with in this study, the real values in all parameters are underestimated. It is possible to say the above, if comparisons are made between the amounts of mushrooms which collectors obtain during their travels. Montoya et al. [21] reported $219.6 \mathrm{Kg}$ of $A$. basii, in one rainy season, and Pacheco-Cobos [22] showed a value of 2,494 fruit bodies of T. floccosus and 2,066 of C. gibba on 55 fungi search paths with persons from San Isidro Buensuceso. This means that there are considerable differences between those species, for the values found in this study.

On the other hand, climatic conditions are one of the key factors for fructification [23], and the climatic information of La Malinche volcano suggests several differences between the two slopes. This is important because rain is one of the most important factors that could affect the soil humidity, nutriment availability, and temperature. However, rains have an irregular distribution in the studied area. Comparing the rain regime with the annual average precipitation, it is observed that San Pablo del Monte (in Southwest slope) is the area with more rains with annual values of $942.7 \mathrm{~mm}$. Values in the municipality of Zitlaltepec, located in the East part, are of $800 \mathrm{~mm}$ of annual rains. These differences affect the availability of plants and other organisms as mushrooms. Another important weather element is temperature because, depending on its values, it could affect the assimilation of several nutrients, minerals, and water. The lowest temperature in Zitlaltepec is $0^{\circ} \mathrm{C}$ during the coldest months, and the maximum temperature is from 20 to $28^{\circ} \mathrm{C}$. San Pablo del Monte is the warmest area, with maximum temperatures from 22 to $28^{\circ} \mathrm{C}$ throughout the year, and its coldest temperature is never under $5^{\circ} \mathrm{C}$. Frosts affect negatively the fruiting of mushrooms; this was observed in this study, during three years of collection. In La Malinche, the highest incidence of frosts is registered from November to February, with an incidence of 60 to 80 days per year [24]. In addition, the characteristics of climatic variables in the study area explain the differences found in the two sampled areas. Information about temperature is important because it affects the level of humidity retention in the soil throughout time, with a beneficial effect in the fruiting of some mushroom species. Apparently, mushroom collection did not affect abundance, production, and frequency of mushrooms, even though there were more frequent visits from mushroom collectors in the Southeast slope than in the Southwest region; nevertheless, it would be convenient to test their actual effect, in experimental plots in the park.

\section{Conclusions}

The results show differences between the two La Malinche slopes regarding production, abundance, richness, and diversity of edible species of mushrooms. Southeast slope presented, in all variables measured, higher values than Southwest slope. However, the availability of mushroom species in space and time is more homogeneous in the Southwest slope, where it is possible to find more species and better distribution during the rainy season. There are few species that dominate the fruit body production in the Southeast slope. We believe that the management of forests by people of different origins (indigenous in the West and mestizo in the East) and the level of commercialization of mushroom species that are important in each slope, as well as the type of forests with their microenvironments, are determinants of those differences.

\section{Conflict of Interests}

The authors declare that there is no conflict of interests regarding the publication of this paper.

\section{Acknowledgments}

Thanks are due to Trinidad Romero, from Javier Mina, who kindly collected mushrooms in the forest with the authors. The authors are also grateful to José Jiménez-López for assisting them with weather information and to Andrea Vera Reyes for the support at soil's Laboratory in Centro de Investigaciones en Ciencias Biológicas, Universidad Autónoma de Tlaxcala (CICB, UAT). The authors are grateful to Héctor Luna for his assistance during field trips. Special thanks are due to the staff of Mycorrhiza Laboratory in the CICB, UAT. This research was supported by CONACyT (Reference no. 980022) and PROMEP (code P/PROMEP UATLAX-200007). Thanks are due to Coordinación General de Ecología, Tlaxcala, for the permissions to enter the Park.

\section{References}

[1] A. Espejel-Rodríguez, N. Santacruz-García, and I. CastilloRamos, "Apropiación, deterioro y conservación de los bosques de la Malinche: una visión retrospectiva," in MatlalcuéYetl: Visiones Populares Sobre Cultura, Ambiente y Desarrollo, P. Castro, Tucker, and T. M. El Colegio de Tlaxcala, Eds., pp. 275-304, CONACYT, Mesoamerican Research Foundation, Tlaxcala, Mexico, 2009. 
[2] A. Kong, A. Montoya, and A. Estrada-Torres, "Hongos macroscópicos," in Biodiversidad Del Parque Nacional Malinche, Tlaxcala, México, F. J. A. Fenández and J. C. López-Domínguez, Eds., pp. 47-72, Coordinación General de Ecología y Gobierno del estado de Tlaxcala, Tlaxcala, Mexico, 2005.

[3] A. Montoya, A. Kong, A. Estrada-Torres, J. Cifuentes, and J. Caballero, "Useful wild fungi of La Malinche National Park, Mexico," Fungal Diversity, vol. 17, pp. 115-143, 2004.

[4] C. Netzáhuatl-Muñoz, "Política de conservación de los recursos del Parque Nacional Malinche," in MatlalcuéYetl: Visiones Populares Sobre Cultura, Ambiente y Desarrollo, P. Castro, Tucker, and T. M. El Colegio de Tlaxcala, Eds., vol. 2, pp. 253-274, CONACYT, Mesoamerican Research Foundation, Tlaxcala, Mexico, 2009.

[5] A. Montoya, E. A. Torres-García, A. Kong, A. Estrada-Torres, and J. Caballero, "Gender differences and regionalization of the cultural significance of wild mushrooms around La Malinche Volcano, Tlaxcala, Mexico," Mycologia, vol. 104, no. 4, pp. 826834, 2012.

[6] E. Hunn, "The utilitarian factor in folk biological classification," American Anthropologist, vol. 84, no. 4, pp. 830-847, 1985.

[7] A. Montoya, O. Hernández-Totomoch, A. Estrada-Torres, A. Kong, and J. Caballero, "Traditional knowledge about mushrooms in a Nahua community in the state of Tlaxcala, México," Mycologia, vol. 95, no. 5, pp. 793-806, 2003.

[8] L. Hernández-Díaz, Evaluación de la productividad de los hongos comestibles silvestres en el Volcán La Malintzi, estado de Tlaxcala [Ph.D. thesis], Departamento de Agrobiología, Universidad Autónoma de Tlaxcala, Tlaxcala, Mexico, 1998.

[9] Instituto Nacional de Estadística, Geografía e Informática, Síntesis Geográfica de Tlaxcala. México D. F. Instituto Nacional de Estadística, Geografía e Informática, Anexo Cartográfico del Estado de Tlaxcala, Tlaxcala, México, 1986.

[10] A. Y. Rossman, R. E. Tulloss, T. E. O'dell, and R. G. Thorn, Protocols for an All Taxa Biodiversity Inventory of Fungi in a Costa Rican Conservation Area, Parkway, Boone, NC, USA, 1998.

[11] G. Guzmán, Los Nombres de los Hongos y lo Relacionado con Ellos en América Latina, Instituto de Ecología A.C., Xalapa, Mexico, 1997.

[12] E. Boa, Wild Edible Fungi. A Global Overview of Their Use and Importance to People, FAO, Rome, Italy, 2004.

[13] Stat-Soft, Statistica 10 Para Windows, Stat-Soft, Tulsa, Okla, USA, 2010.

[14] R. Garibay-Orijel, M. Martínez-Ramos, and J. Cifuentes, "Disponibilidad de esporomas de hongos comestibles en los bosques de pino-encino de Ixtlán de Juárez, Oaxaca," Revista Mexicana De Biodiversidad, vol. 80, pp. 521-534, 2009.

[15] J. F. Rohlf, Numerical Taxonomy and Multivariate Analysis System. Version 2.1, Applied Biostatistics, New York, NY, USA, 2000.

[16] Ø. Hammer, D. A. T. Harper, and P. D. Ryan, "Past: paleontological statistics software package for education and data analysis," Palaeontologia Electronica, vol. 4, no. 1, pp. 19-20, 2001.

[17] M. Moser, Keys to Agarics and Boleti (Polyporales, Boletales, Agricales, Russulales), Roger Phillips, London, UK, 1983.

[18] G. D. Lincoff, H. Mitchel, and I. E. Liberman, Toxic and Hallucinogenic Mushroom Poisoning, Van Nostrand Reinhold Company, New York, NY, USA, 2001.

[19] M. C. Zamora-Martínez and C. Nieto de Pascual-Pola, "Natural production of wild edible mushrooms in the southwester rural territory of Mexico City, Mexico," Forest Ecology and Management, vol. 72, no. 1, pp. 13-20, 1995.
[20] T. G. E. Anahid, Estudio ecológico y frecuencia de mención de los hongos silvestres en el Parque Nacional La Malinche, Tlaxcala [Ph.D. thesis], Facultad de Ciencias Universidad Nacional Autónoma de México, Mexico City, Mexico, 2009.

[21] A. Montoya, N. Hernández, C. Mapes, A. Kong, and A. EstradaTorres, "The collection and sale of wild mushrooms in a community of Tlaxcala, Mexico," Economic Botany, vol. 62, no. 3, pp. 413-424, 2008.

[22] L. Pacheco-Cobos, Análisis de las trayectorias de búsqueda de recursos forestales: el caso de la recolección de hongos en San Isidro Buensuceso, Tlaxcala [Ph.D. thesis], Facultad de Ciencias, Universidad Nacional Autónoma de México, Distrito Federal, Mexico, 2010.

[23] I. Brunner, F. Brunner, and G. A. Laursen, "Characterization and comparison of macrofungal communities in an Alnus tenuifolia and an Alnus crispa forest in Alaska," Canadian Journal of Botany, vol. 70, no. 6, pp. 1247-1258, 1992.

[24] M. Hernández-López and J. Jiménez-López, "El clima de la Matlalcueye y el conocimiento tradicional," in MatlalcuéYetl: Visiones Populares Sobre Cultura, Ambiente y Desarrollo, C. P. Tucker and T. M. El Colegio de Tlaxcala, Eds., pp. 109-134, CONACYT, Mesoamerican Research Foundation, Tlaxcala, Mexico, 2009. 

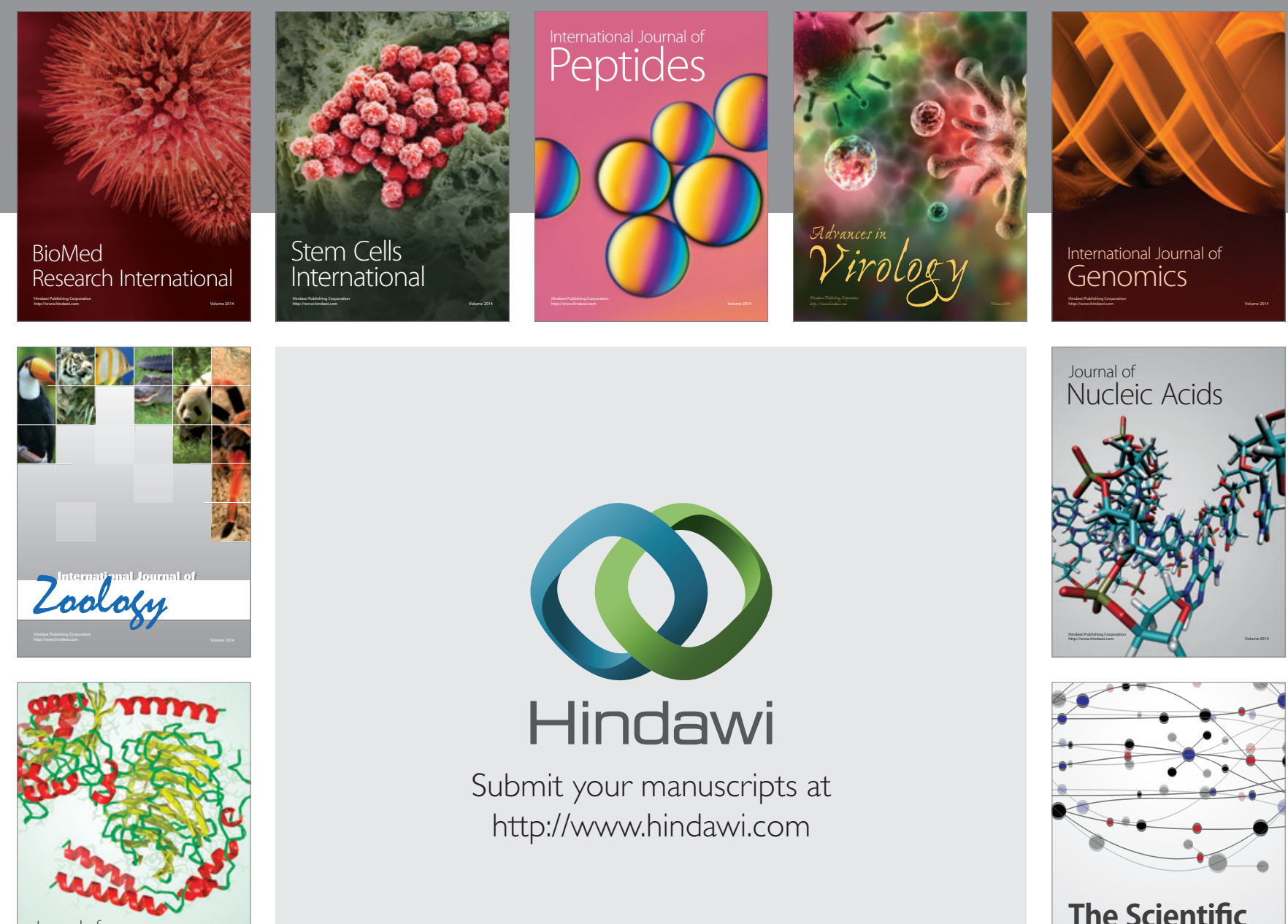

Submit your manuscripts at

http://www.hindawi.com

Journal of
Signal Transduction
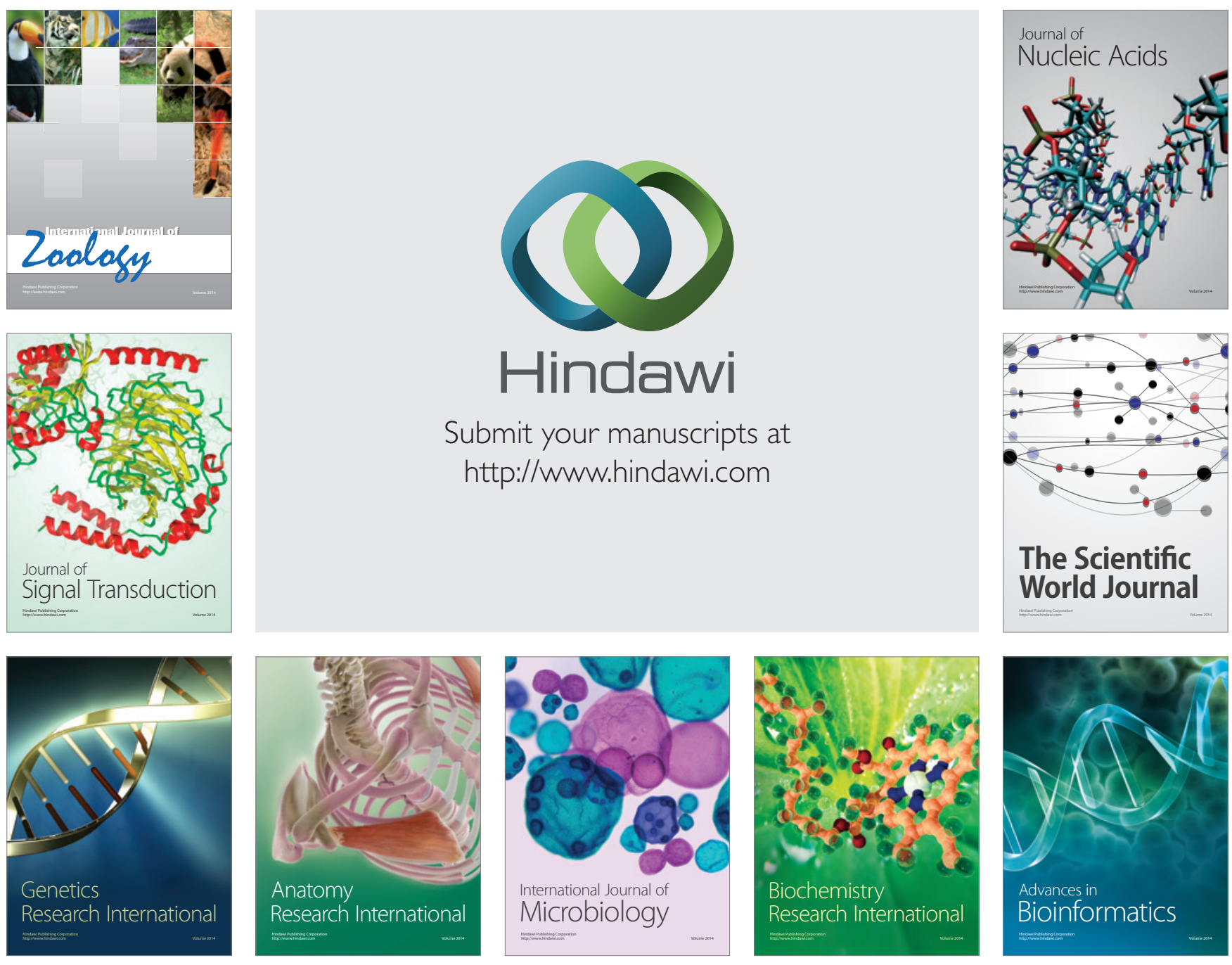

The Scientific World Journal
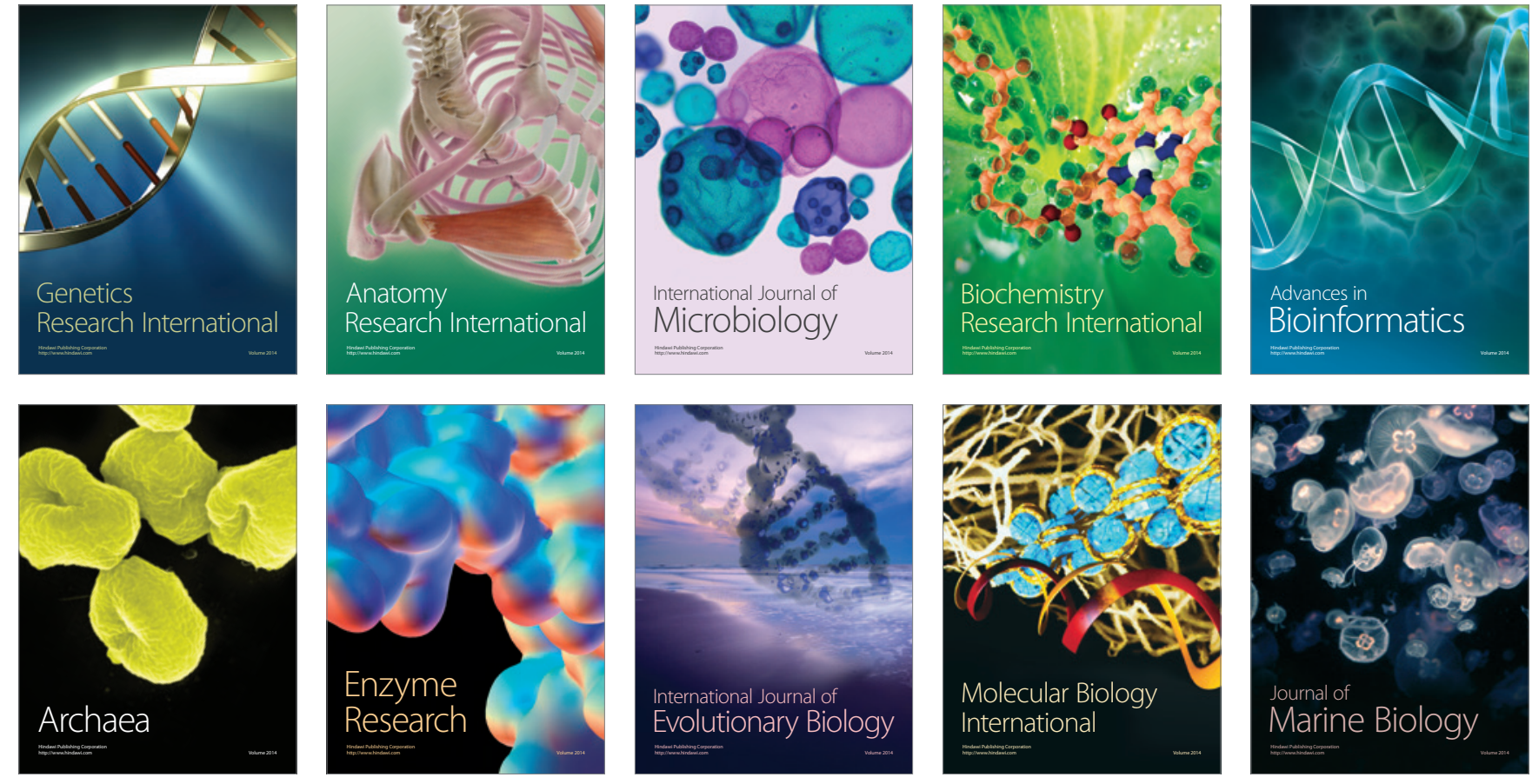